\title{
Modernism as Projected through the Character of Vladimir in Samuel Beckett's Waiting for Godot
}

\author{
Eileen Shannon \& Hirmawan Wijanarka \\ hir101@usd.ac.id \\ Department of English Letters, UniversitasSanata Dharma
}

\begin{abstract}
Samuel Beckett's Waiting for Godot, a play published in 1948, not long after the break of World War II, displays absurdity through its theme, plot, setting and characters. Despite the postmodern label on the literary work itself, this article assumes that there are ideas of modernism contained within it, projected through the character of Vladimir. Six characters are analyzed in this study. They are Vladimir, Estragon, Pozzo, Lucky, and the Boy. Among these characters, Vladimir tends to be more of a modernist rather than a postmodernist. This is shown in his act of waiting for Godot while the others do not really concern about the relevance of Godot in determining the outcome of their fates. Vladimir rests his faith and hope in Godot, persuading his fellow tramp Estragon to accompany him during his wait. Vladimir's critical thinking and quest for answers give a clear place to stand for the other characters who don't present the importance of logical thinking. Vladimir stands out as a character with modernist values such as anticipating, reasoning, and relevant discoursing.
\end{abstract}

Keywords: modernism, postmodernism, Samuel Beckett

\section{Introduction}

Samuel Beckett (1906-1989) was an Irish playwright, poet and novelist who was strongly influenced by his fellow Irish writer, James Joyce, which resulted in Beckett being considered as the last of the modernists. However, he is also considered as one of the fathers of the postmodernist movement in literature. Waiting for Godot happens to be Beckett's first play which was originally written in French (which he then translated into English by himself), published back in 1948 and known for the absurdity of its content. The tragicomedy in two acts was first staged on 19 November 1957 before an audience that consisted of fourteen hundred convicts at the San Quentin Penitentiary (Esslin, 1968: 19).

Considering its publishing period and other features such as existential crisis, identity crisis and absurdity, it can be clearly seen that the play tends to be one of the postmodern literature. Moreover, Waiting for Godot is also a leading play in The Theatre of the Absurd, written by Martin Esslin in 1961, a theatrical outcome of postmodernism, which was inspired by Existential philosophy and its view that human condition is basically meaningless (Camus, 1942: 18).

Postmodernism is the term used to suggest a reaction or response to modernism in the late twentieth century. "Modernism began in the 1890s and lasted until about 1945, while postmodernism began after the second world war, especially after 1968" (Abrams, 1993: 118-120). This implies that postmodernism took place after modernism, making it seem like a form of continuity from modernism. In fact, postmodernism does not continue modernism; it is rather a countereffect of it.

Modernism is based on using rational, logical means to gain knowledge while postmodernism denied the application of 
logical thinking. Rather, the thinking during the postmodern era was based on unscientific, irrational thought process, as a reaction to modernism (Abrams, 1993: 120). A hierarchical, organized and determinate nature of knowledge is known as the characteristics of modernism. Postmodernism lacked the analytical nature and thoughts were rhetorical and completely based on belief. The fundamental difference between modernism and postmodernism is that modernist thinking is about the search of an abstract truth of life while postmodernist thinkers believe that there is no universal truth, abstract or otherwise. "In a word, the modernist laments fragmentation while the postmodernist celebrates it" (Barry, 2002: 84).

Postmodernism argues that there is no absolute truth in the universe. Rules of classical literary works are not valid in this case. There is no unity of time, place and action in literary works of postmodernism. Unlike classical literary works, there is no hero. Waiting for Godot was written in the second half of the twentieth century and arose similarities between postmodernism and the play.

Although Waiting for Godot is admitted worldwide as a literary product of postmodernism, some aspects of modernism are reserved in the play through the character of Vladimir. This article aims at answering these questions: (1) How are Vladimir, Estragon, Pozzo, Lucky and the Boy described in Samuel Beckett's play Waiting for Godot? and (2) How does Vladimir project the ideas of modernism among other characters in Samuel Beckett's play Waiting for Godot?

\section{Modernism and Postmodernism}

Starting with the most general definition of Modernism, the term is widely used to identify new and distinctive features in the subjects, forms, concepts, and styles of literature and the other arts in the early decades of the present (twentieth) century, but especially after World War I (1914-1918) (Abrams, 1993: 118-119). This term is also likely to be related to 'Enlightenment', another term defining an era where human beings held on to a rational way of thinking in search for a universal truth.

In terms of literature, Abrams stated that Modernism could be defined as a movement due to World War I. The term Modernism is widely used to identify new and distinctive features in the subjects, forms, concepts, and styles of literature and the other arts in the early decades of the present (20th) century, but especially after World War I (1914-1918) (1993: 118-119).

In general, according to Winquist, modernism is the name given to the literary, historic, and philosophical period from roughly 1890-1950, which was marked by the belief in the unity of experience, the predominance of universals, and a determinate sense of referentiality (2001: 251).

Both Abrams and Winquist imply that the idea of modernism was commonly brought out during the first half of the twentieth century. Their theories also mention the term 'universals' or 'universal truth', meaning to convey that the purpose of modernism (in this case, literature) is to create only one truth instead of versions of truth, believing that human experience can somehow be unified in literature. MadanSarup states that

The basic features of modernism can be summarized as: an aesthetic selfconsciousness and reflexiveness; $a$ rejection of narrative structure in favour of simultaneity and montage; an exploration of the paradoxical, ambiguous and uncertain, open-ended nature of reality... (1993: 131)

When speaking of pure modernism, Sarup's statement here emphasizes that it is about experimentation and the aim of finding an inner truth behind surface appearance, which is an abstract truth.

While modernist thinking is about the search of an abstract truth of life, postmodernist thinkers believe that there is no universal truth, abstract or otherwise. 
Postmodernism argues that there is no absolute truth in the universe. Rules of classical literary works are not valid in these literary works. There is no unity of time, place and action in literary works in postmodernism.

Still about postmodernism in general, as stated by Terry Barett in Abrams', postmodernism does not merely chronologically follow modernism, it reacts against modernism, and might better be called antimodernism. The term postmodernism is sometimes applied to the literature and art after World War II (19391945) (1993: 120).

Following Barett's statement in Abrams', postmodernism happens to be a breakthrough or to be more exact, a counter towards modernism, in a way that these terms have their own traits and characteristics. The term postmodernism originated among artists and critics in New York in the 1960s and was taken up by European theorists in the 1970s (Sarup, 1993: 131). Sarup in An Introductory Guide to Post- Structuralism and Postmodernism wrote that

One of them (the artists), Jean-Francois Lyotard, in a famous book entitled The Postmodern Condition, attacked the legitimating myths of the modern age, the progressive liberation of humanity through science, and the idea that philosophy can restore unity to learning and develop universally valid knowledge for humanity. Postmodern theory became identified with the critique of universal knowledge and foundationalism (1993: 132).

This signifies the deletion of boundaries such as boundaries between art and everyday life, elite and popular culture, stylistic eclecticism and code mixing. So postmodernists assume that there is no reason (universal truth), only reasons (many versions of truth). Lyotard in Sarup also said that in postmodernism there is:

A shift of emphasis from content to form or style; a transformation of reality into images; the fragmentation of time into a series of perpetual presents. There are continual references to eclecticism, reflexivity, self-referentiality, quotation, artifice, randomness, anarchy, fragmentation, pastiche and allegory (1993:132).

In the context of literature, this implies that the concept of postmodernism has a style of referring to a larger context (the metadata) outside of its own, repeating things, forming series of scenes which do not define the time nor place and most of the time breaking the conventional rules made up by society (the act of anarchy).

\section{Vladimir (Didi) in Waiting for Godot}

As the dominating one, Vladimir seriously takes responsibility over his partner, Estragon. Most of the time, Estragon appears to be dependent on Vladimir. Vladimir even once said to Estragon that "It's too much for one man" (Beckett, 1972: 10). This shows Vladimir's personality as a dominating person. Vladimir also worries that if they do eventually part and go their own ways, Estragon would not be able to make it. Vladimir has a scant hope for Estragon's survival since Estragon had been so much relying on him.

ESTRAGON. (coldly). There are times when I wonder if it wouldn't be better for us to part.

VLADIMIR. You wouldn't go far. (Beckett, 1972: 16)

Vladimir's response towards Estragon's intention of parting, actually resembles his idea of Estragon's dependency on him. He knows that Estragon is weak because all this time it is Vladimir who has been taking care of him; he feeds and nurtures him, even comforts him when he wakes up from his nightmares.

Of the two, Vladimir is the more religious one, the truth seeker, while Estragon is ignorant about it and shows more interest in looking at pictures of colorful maps in the Bible instead of the sermons in it. 
VLADIMIR. Did you ever read the Bible? ESTRAGON. The Bible... (He reflects). I must have taken a look at it.

VLADIMIR. Do you remember the Gospels? ESTRAGON. I remember the maps of the Holy Land. Coloured they were. Very pretty. The Dead Sea was pale blue. The very look of it made me thirsty. That's where we'll go, I used to say, that's where we'll go for our honeymoon. We'll swim. We'll be happy. (Beckett, 1972: 12)

Vladimir in fact reads the Bible and is critical about it. He is critical towards the fact that only one of the gospels admits that one of the thieves crucified next to Christ was saved, while other gospels tell none of the thieves were saved (Beckett, 1972: 13). Estragon, on the other hand, did not really care much about why people choose to believe that one gospel instead of the other three.

In their first encounter with Pozzo and Lucky, it is Vladimir who dares to confront Pozzo, making himself appear to be man of the action. He shows compassion towards Lucky's condition.

VLADIMIR. (exploding). It's a scandal! Silence. Flabbergasted, Estragon stops gnawing, looks at Pozzo and Vladimir in turn. Pozzo outwardly calm. Vladimir embarrassed.

POZZO. (to Vladimir). Are you alluding to anything in particular?

VLADIMIR. (stutteringly resolute). To treat a man... (gesture towards

Lucky)... like that... I think that... no... a human being... no... it's a scandal!

(Beckett, 1972: 27)

He could not stand the sight of Lucky being enslaved by Pozzo for it was inhumane, sickening and scandalous. Vladimir's humanist sense doesn't allow him to bear any suffering that happens around him. He hates to see this, and even interrogates himself "was I sleeping while the others suffered?" (Beckett, 1972: 90). He carries a feeling of guilt, assuming that he has done little or perhaps nothing to improve the miseries of others. He even refuses to listen to stories of Estragon's nightmares.
ESTRAGON. I had a dream.

VLADIMIR. Don't tell me! ESTRAGON. I dreamt that-

VLADIMIR. DON'T TELL ME!

ESTRAGON. (gesture towards the universe). This one is enough for you? (Silence). It's not nice of you, Didi. Who am I to tell my private nightmares to if I can't tell them to you? (Beckett, 1972: 15-16)

Vladimir is always the one who is strongwilled in waiting for Godot. Everytime Estragon suggests to leave, Vladimir always restrains him with the same reason: because they have to wait for Godot. This happens about seven times throughout the play, showing his commitment in the act of waiting for Godot who might never come.

By the end of Act 1, Vladimir shows his optimism by assuring Estragon that "Tomorrow everything will be better". He is determined that something good is about to happen soon, like the attendance of Godot.

\section{VLADIMIR. We've nothing more to do here. \\ ESTRAGON. Nor anywhere else. VLADIMIR. Ah Gogo, don't go on like that. Tomorrow everything will be better. ESTRAGON. How do you make that out? VLADIMIR. Did you not hear what the child said? ESTRAGON. No. \\ VLADIMIR. He said that Godot was sure to come tomorrow. (Beckett, 1972: 52-53)}

In Act 2, when that 'tomorrow' comes, Vladimir recalls the events that happened on the previous day about Pozzo and Lucky, the tree and pretty much what they had been doing. Vladimir appears to be the one with the strongest memory of all characters. While others fails to recall past events properly, Vladimir is certain about his own memories. He always ends up reminding Estragon -and Pozzo- whenever they forget things. Once, he said to Estragon "you forget everything" (Beckett, 1972: 48).

Being the more religious and committed one, Vladimir holds on to his belief in salvation. $\mathrm{He}$ is certain that salvation is to come, and their savior is Godot himself. At the 
end of Act 2, Vladimir states this belief of his about Godot when Estragon persuades him to hang themselves.

VLADIMIR. We'll hang ourselves tomorrow. (Pause). Unless Godot comes. ESTRAGON. And if he comes?

VLADIMIR. We'll be saved. (Beckett, 1972: 94)

Another time, Vladimir expresses his happiness and joy in thinking that Godot has finally arrived. Both Vladimir and Estragon were just passing the time, doing nothing meaningful when suddenly they heard voices of people approaching. Triumphantly, Vladimir cries "It's Godot! At last! Gogo! It's Godot! We're saved! Let's go and meet him!" (Beckett, 1972: 73)

In the second act, Vladimir tries to convince Estragon to do something. To him, they have wasted plenty of their time just on waiting and arguing and just doing some idle discourse'. Vladimir's action is shown in the scene where Pozzo cries for help for someone to help him get up.

VLADIMIR. Let's not waste our time in idle discourse!

(Pause. Vehemently). Let us do something, while we have the chance! It is not every day that we are needed. Not indeed that we personally are needed. [...] Let us make the most of it, before it's too late! Let us represent worthily for once thefoul brood to which a cruel fateconsigned us! What do you say? (Beckett, 1972: 79)

Vladimir realizes that they are wasting their time, and he finally gets bored in just waiting. He considers their act of waiting as 'nothingness' which does not give any meaning to him, unless he makes something useful of his time.

VLADIMIR. We wait. We are bored. (He throws up his hand).

No, don't protest, we are bored to death, there's no denying it. Good. A diversion comes along and what do we do? We let it go to waste. Come, let's get to work! (He advances towards the heap, stops in his stride). In an instant all will vanish and we'll be alone once more, in the midst of nothingness!

He broods. (Beckett, 1972: 81).

Vladimir relies more on his ability to think, making it crucial for him to use his intelligence and critical thinking in almost all his (or Estragon's) actions. At times, he even does the thinking for Estragon. In the scene where Lucky is demanded to entertain the others, Vladimir prefers the intellectual diversion in wanting to listen to what Lucky thinks instead.

POZZO. Who! You know how to think, you two?

VLADIMIR. He thinks?

POZZO. Certainly. Aloud. [...]

Well, would you like him to think something for us?

ESTRAGON. I'd rather he'd dance, it'd be more fun?

POZZO. Not necessarily.

ESTRAGON. Wouldn't it, Didi, be more fun?

VLADIMIR. I'd like well to hear him think. (Beckett, 1972: 39)

In conclusion, Vladimir is a type of person who has a stronger sense of moral judgment than the other characters, but is still bestowed with a sense of indecisiveness. His constant peering into the hat and his walking back and forth are indications of his restless spirit and a longing for stability. At one point he becomes so frustrated with his lack of action that he nearly despairs. Vladimir is the most committed, the most constant. He reminds Estragon that they must wait for Godot. Perhaps this is simply because his memory is sharper; he remembers many things that Estragon seems to have forgotten.

\section{Modernism in Vladimir in Waiting for Godot}

Being aware that this thesis uses the New Criticism approach in analyzing the characters and in relating their characteristics to the ideas of modernism and postmodernism, the writer limits the analysis inside the object of the study, focusing on the characters. The analysis refers to only the ideology of modernism and postmodernism 
as the extrinsic elements of the object of the study.

In Waiting for Godot, Vladimir appears to be the center of the play, in fact playing a role as the hero or protagonist. Though many have assumed that Vladimir and Estragon are both the protagonists, this research shows how Vladimir controls most conversations and even Estragon's motivation in the play.

The analysis of the characters shows how the characters have several points that can define their characteristics and ideas. Vladimir is one of the two main characters who shows dominance over the other, and most of the time does the thinking. Estragon could not really rely on himself to think because he has a problem with his memory (just like the other characters in the play). This implies that Vladimir is the only character who has a good memory.

Previously in this thesis, it has been explained that modernism thinking is based on using rational and logical means to gain knowledge while postmodernism denies the application of logical thinking. Rather, the thinking during the postmodern era was based on unscientific, irrational thought process, as a reaction to modernism (Abrams, 1993: 120). In this section, the thesis discusses the ideas of modernism in Vladimir and also the ideas of postmodernism in the other characters. An overview of the other characters in the play is conducted in order to give a contrast to the character of Vladimir.

\section{The Act of Anticipating}

The first aspect from Vladimir's modernist ideas to be analyzed is his act of anticipating. From the very beginning of the play, Vladimir shows his determination in waiting for this person or entity named Godot who never shows up, believing that he will eventually come. He has never met this Godot before, and it is strange enough for someone to just be waiting on a person to come without knowing exactly what their purpose of waiting is. Estragon could not tell why he waits for Godot because he only relies on Vladimir to provide him the reason why. All
Vladimir knows is that he waits because he seeks for salvation. Salvation from Godot.

ESTRAGON. And if he comes?

VLADIMIR. We'll be saved. (Beckett, 1978:

94)

Vladimir waits dearly for Godot, his savior, and always restrains Estragon from giving up on the wait. $\mathrm{He}$ in fact needs someone to accompany him during his wait, because he knows that he will feel lonely. He even manipulates Estragon to stay with him, telling him that he (Estragon) will never make it alone. Estragon seems quite certain of his intentions of leaving Vladimir, but he remains stuck with him.

Although it seems as if both Vladimir and Estragon are waiting for Godot, the writer finds it differently. The only reason why Estragon still sticks around is because of his dependency on Vladimir, not his pure intentions in waiting the endless wait for Godot. Vladimir takes care of Estragon who frequently suffers from physical pain, and both of them take advantage of this condition; Vladimir has a friend to accompany him during his wait while Estragon has someone to rely on to feed him and think for him.

ESTRAGON. You see, you feel worse when I'm with you. I feel better alone, too.

VLADIMIR. (vexed). Then why do you always come crawling back?

ESTRAGON. I don't know.

VLADIMIR. No, but I do. It's because you don't know how to defend yourself. I wouldn't have let them beat you. (Beckett, 1978: 59)

The conversation above is a very strong piece from the play that can prove how Vladimir is the only one waiting for Godot. Although Vladimir at times seems irritated by the presence of Estragon (even Estragon senses this), he couldn't stand the feeling of being alone. Even when Estragon falls asleep, he wakes him up just because he feels lonely. He uses Estragon's dependency to manipulate him to stay with him.

ESTRAGON. And if we dropped him? (Pause). If we dropped him? 
VLADIMIR. He'd punish us. (Beckett, 1978: 93)

Estragon really shows his intentions of giving up the wait. He does not really care much about Godot and even assumes that the responsibility to wait for Godot rests on Vladimir. At the end of each Acts, it is Vladimir whom the Boy approaches and delivers Godot's message to. This makes it even clearer that Vladimir has the role of waiting for Godot. Estragon even mentions Godot as "your man" to Vladimir, giving the impression of being satirical and leaving it all up to Vladimir to take actions (Beckett, 1978: 21).

Modernism emphasizes experimentation and the aim of finding an inner truth behind surface appearance (Sarup, 1993: 131). Vladimir has the need to prove that Godot will eventually show up and offer him the salvation he has been waiting for. Although Godot remains unseen, Vladimir wishes to see him in person one day and finally unveil Godot, who is an abstract truth.

\section{The Act of Reasoning}

The next modernist aspect of Vladimir is his act of reasoning, or, in other words, thinking. Vladimir shows interest in thinking, and makes it a good habit of his. He often contemplates conditions or circumstances, wanting to find out the reasons why these things occur. Thinking, is an activity which keeps Vladimir sober and conscious most of the time, and he needs to maintain this to put life into his actions.

Modernist people concern more about how they see rather than what they see (Barry, 2002: 82). So the main question is "how" or "why" instead of just "what". The characters in the play, except for Vladimir, show their disinterest in thinking. Apart from the difficulty they go through in recalling past events, they tend to just give up on thinking or not try hard enough to even do it. Lucky does not think for himself because it is Pozzo who gives him orders, telling him what to do. Once he thinks, only nonsensical words come out (while Pozzo calls this "thinking"). Pozzo even stopped Lucky's action of thinking by removing the hat from Lucky's head exclaiming "there's an end to his thinking!" (Beckett, 1978: 45).

Pozzo does not go far in thinking because he has a short span of focus, forgetting his purposes due to any smallest distraction. He tends to ignore having to do reasoning for his actions, intentions or his conditions. $\mathrm{He}$ sometimes asks questions but does not really mind if they are answered or not. Here, Pozzo shows characteristics of being postmodern, lacking the analytical nature and having rhetorical thoughts (open ended questions). There is a time when Vladimir is trying to find out the reason for Pozzo's blindness, repeatedly asking Pozzo why. Pozzo then bursts into fury, expressing his feeling of being tormented by questions. He doesn't care why he has gone blind or why Lucky is dumb, because for him, to ponder these things is just a waste of time (Beckett, 1978: 89).

The moment when Pozzo offers to put Lucky on a show to entertain the tramps, Vladimir chooses to hear him think while Estragon is interested in seeing him dance (Beckett, 1978: 39). This adds to Vladimir's act of reasoning, wanting to know how others think.

Vladimir takes thinking seriously. He tries to explain to Estragon that there is nothing wrong in thinking. What is wrong is to "have thought", in other words, only guessing and relying on mere belief.

VLADIMIR. When you seek you hear. ESTRAGON. You do.

VLADIMIR. That prevents you from finding.

ESTRAGON. It does.

VLADIMIR. That prevents you from

thinking.

ESTRAGON. You think all the same.

[...]

VLADIMIR. We're in no danger of ever thinking anymore.

ESTRAGON. Then what are we complaining about?

VLADIMIR. Thinking is not the worst. [...]

VLADIMIR. What is terrible is to have thought. (Beckett, 1978: 64) 
The Boy does not show much effort in thinking or reasoning. When being asked, most of the time he only gives short answers, simply by saying "yes, sir", "no, sir", or even "I don't know, sir". Vladimir gets frustrated when conversing with the Boy because he (the Boy) doesn't seem to have initiative in thinking of anything else to say apart from answering questions. Every time Vladimir stops asking questions, the Boy only remains silent.

\section{The Act of Relevant Discoursing}

The third modernist idea to be analyzed is Vladimir's act of relevant discoursing. While the previous discussion concerns about the act of reasoning or thinking, this part discusses the type or manner of conversations that are developed from Vladimir's reasoning. So in order to express ideas and thoughts, a discourse or conversation can be one of the ways to do it.

Throughout the play, from the beginning until the end, Vladimir and Estragon pass the time by conversing with each other, sometimes getting into a debate or argument, then talk about random things and so on. They seem to always find something to talk about, whether it makes sense (relevant) or not. For Vladimir, it is crucial to find something worthy enough to talk about so that they don't pass the time in doing nothing useful.

Reasoning is a must for Vladimir, but only doing it without considering the discourse to be relevant is not good enough. His words and actions have to be meaningful and purposeful, otherwise he will only think of himself as useless, worthless and idle. That moment when he hears Pozzo's cry for help, he becomes enlightened and right away figures out something to make out of it.

VLADIMIR. Let us not waste our time in idle discourse! Let us do something, while we have the chance! It is not every day that we are needed. Not indeed that personally we are needed.

[...]

Let us make the most out of it, before it is too late! Let us represent worthily for once the foul brood to which a cruel fate consigned us! What do you say? (Beckett, 1978: 79)

Vladimir supposes that he has been wasting his time doing idle discourse with his partner Estragon, blathering about irrelevant things that do not improve their current state of being. These things they talk about such as the story of two thieves or a man who went to a brothel house, memories of good old times and even plans of committing suicide. They even play roles as Pozzo and Lucky, take a boot on and off, peer into hats and sing or sleep. Both Vladimir and Estragon labor themselves in these idle discourses and activities, but eventually, Vladimir gets fed up doing this and realizes that he should be doing something else more important.

VLADIMIR. Well? What do we do? ESTRAGON. Don't let's do anything. It's safer. (Beckett, 1978: 18)

VLADIMIR. You'd rather be stuck here doing nothing? ESTRAGON. Yes.

VLADIMIR. Please yourself. (Beckett, 1978: 71)

At the point when Vladimir comes to realize their being idle, he then tries to think of something to do. On the other hand, Estragon seems to put aside the need to make something useful and meaningful out of their time, instead, when he (Estragon) feels bored or hopeless, all he thinks of is just to fall asleep, leave or just commit suicide. He's only bored waiting and runs out of things (anything) to do.

Pozzo and Lucky only happens to pass by from nowhere to nowhere and not really do anything distinctive from what Vladimir and Estragon have been doing, which is the act of pointless blathering. Pozzo and Lucky talk about things but do not make up their minds of what to do, only to just be going "on" and Vladimir and Estragon to just be "waiting for Godot". They all just go back to the start; Pozzo not sure where to go and the tramps not sure what to do.

VLADIMIR. We wait. We are bored. (He throws up his hand). 
No, don't protest, we are bored to death, there's no denying it. Good. A diversion comes along and what do we do? We let it go to waste. Come, let's get to work!

(He advances towards the heap, stops in his stride).

In an instant all will vanish and we'll be alone once more, in the midst of nothingness!

He broods. (Beckett, 1978: 81)

Vladimir feels that they should not waste a good chance to finally do something useful, a purposeful action to save them from their deadly boredom and state of nothingness. Vladimir needs to prove himself worthy for once and not get carried away in idle discourse during the wait.

\section{Closing Remarks}

The second objective is to reveal the ideas of modernism in Vladimir. As said previously in this thesis, Vladimir seems to be the only sane person among the other characters. Though perhaps Estragon could also be counted as being sane, Vladimir is one step ahead of him due to Estragon's defective memory. He has shown signs of being the odd one, having different a different behavior and point of view. He is the only one determined to wait for Godot because he believes in salvation and that Godot is his savior. He gets frustrated when he comes to think of nothing meaningful to do. Vladimir contemplates the Bible while Estragon only admires it from the interesting looking pictures in it. When nobody remembers anything that happened on the previous day, he is the only one who can recall his memories and feel confident to rely on them. He also questions the reality at them time he becomes frustrated; he wonders if he is sober or asleep.

From the result of the analysis, the ideas of modernism in the play can be seen through the character of Vladimir marked by his acts of anticipating, reasoning, and relevant discoursing. Through Vladimir, the postmodern play itself is able to convey its ideas of modernism by creating a contrast between the two ideologies; between Vladimir and the rest of the characters.

\section{References}

Abrams, M.H. A Glossary of Literary Terms Seventh Edition. New York: Heinle \& Heinle, 1993.

Barry, Peter. Beginning Theory An Introduction to Literary and Cultural Theory. Manchester: Manchester University Press, 2002.

Beckett, Samuel. Waiting for Godot: A Tragicomedy in Two Acts. London: Faber and Faber, 1972.

Camus, Albert. Le Mythe de Sisyphe. Paris: Gallimard, 1942.

Currie, W.T. Brodie's Notes on Samuel Beckett's Waiting for Godot. Suffolk: The Chaucer Press, 1978.

Esslin, Martin. The Theatre of the Absurd. New York: Anchor Books Doubleday \& Company, Inc., 1968.

Hapsari, Louciana. "The Idea of Modernism as Revealed through Character and Plot in Luigi Pirandello's Six Characters in Search of an Author" Undergraduate Thesis. Yogyakarta: Universitas Sanata Dharma, 2014.

Henkle, Roger B. Reading the Novel: An Introduction to the Techniques of Interpreting Fiction. Michigan: Harper \& Row, 1977.

Murphy, M.J. Understanding Unseens: An Introduction to English Poetry and The English Novel for Overseas Students. Oxford: George Allen \& Unwin Ltd, 1972.

Nawaningrum, Theresia. "The Contribution of Minor Characters toward the Main Characters' Motivation in the Act of Waiting in Samuel Beckett's Waiting for Godot" Undergraduate Thesis. Yogyakarta: UniversitasSanata Dharma, 2002.

Reaske, C.R. How to Analyze Drama. New York: Monarch Press, Inc., 1966. 
Eileen Shannon \& Hirmawan Wijanarka

Roberts, Edgar V. and Henry E. Jacobs. Fiction: An Introduction to Reading and Writing. New Jersey: Prentice-Hall, Inc., 1989.

Sarup, Madan. An Introductory Guide to PostStructuralism and Post- Modernism. Horlow: Longman, 1993.

Winquist, Charles E. and Victor E. Taylor. Encyclopedia of Postmodernism. London: Routledge, 2001. 